\title{
Poetas-críticos: o paradoxo da paródia na lírica de Amaral e de Britto
}

\author{
Rosângela Aparecida Cardoso ${ }^{1}$
}

RESUMO: Este artigo investiga a paródia no poema "Em Creta, com o dinossauro", de Ana Luísa Amaral, e no poema "Um pouco de Strauss", de Paulo Henriques Britto, elucidando o cânone descanonizado que perpassa a (re)criação poética amalgamado à reflexão sobre o locus crítico da poesia no mundo contemporâneo.

ABSTRACT: This essay investigates the parody in the poems "Em Creta, com o dinossauro" by Ana Luísa Amaral and "Um pouco de Strauss" by Paulo Henriques Britto, in an attempt to explain the intertextuality and reflexive thematization of poetry in the field of contemporary poetic production.

PALAVRAS-CHAVE: Paródia; Ana Amaral; Paulo Britto

KEYWORDS: Parody; Ana Amaral; Paulo Britto

Este artigo tem por objeto perscrutar o esfolhamento das tradições que, de acordo com os pressupostos teóricos de Nunes (1991, p. 179), significa "a conversão de cânones, esvaziamento de sua função normativa, em fontes livremente disponíveis com as quais incessantemente dialogam os poetas", ou seja, o usufruto dos poetas atuais de todo cânone, porém descanonizado. Partindo da premissa de que a intertextualidade é um dos traços dominantes da poesia portuguesa e brasileira das últimas décadas, nosso foco de interesse incide sobre a finalidade da paródia na poética de Amaral e de Britto, enquanto expressão de um novo relacionamento com as tradições mais recentes ou mais distantes. Para tal, investigamos a convergência e o entrecruzamento das múltiplas sendas percorridas pela portuguesa Ana Luísa Amaral no poema "Em Creta, com o dinossauro", pertencente ao livro E muitos os caminhos (1995), e pelo brasileiro Paulo Henriques Britto no poema "Um pouco de Strauss", pertencente ao livro Trovar claro

1 Doutoranda em Letras e Linguística da Universidade Federal de Goiás (Bolsista da CAPES). Email: rosangelaacardoso@hotmail.com. 
(1997), que são textos outros, de cronotopias distintas. Apresentamos, dessa forma, uma constante que configura "o híbrido perfil poético dessa cena literária móvel do presente: a tematização reflexiva da poesia ou a poesia sobre poesia" (NUNES, p.179).

No âmbito dessa questão, cumpre-nos ressaltar que a linguagem do poema, em conformidade com a teoria de Barbosa (1986, p. 36), permite leitura sucessiva da multiplicidade das linguagens no espaço e no tempo. No espaço da poética, infiltrado pela permanente passagem de outras linguagens, a linguagem poética erigida pelo movimento tradição/tradução é um instante individual dos tempos da linguagem.

Segundo a teoria de Barbosa (1986, p. 14), a linguagem do poeta é a "tradução/traição" da consciência de leitura, posto que "começar o poema equivale a repensar a sua viabilidade através da armação de novos enigmas cuja solução o leitor há de procurar não somente na personalidade do poeta mas naquilo que [...] aponta para a saturação dos usos da linguagem". Essa é a justificativa para sondarmos o "cânone descanonizado" na personalidade do poeta Britto e da poeta Amaral e no indício do trajeto de leituras de cada um deles.

A historicidade do poema moderno incorpora, além das relações entre o poeta e as circunstâncias cronotópicas, o nível de envolvimento intertextual engendrado. Portanto, para os poetas Britto e Amaral, a consciência histórica implica a cultural, porquanto se estabelece no texto poético uma relação de dependência entre a condição de sedução e a condição de enigma, conforme preconiza Barbosa (1986, p. 15): "o novo enigma é a resolução transitória de numerosos enigmas anteriores".

Com o intuito de elucidarmos a maneira pela qual os mecanismos da tradição estão sendo revistos na atual produção poética de Portugal e de Brasil, nosso enfoque do paradoxo da paródia nos poemas "Em Creta, com o dinossauro" e "Um pouco de Strauss" investiga a convergência entre a tese postulada por Kristeva (1974, p. 176), segundo a qual "os textos da modernidade [...] se constroem absorvendo e destruindo, concomitantemente, os outros textos do espaço intertextual", e a tese defendida por Hutcheon (1989, p. 48), consoante a qual "o prazer da ironia da paródia [...] [provém] do grau de empenhamento do leitor no 'vaivém' intertextual [...] entre cumplicidade e distanciamento".

A natureza textual ou discursiva da paródia é elucidada em seu elemento constitutivo odos, cujo significado é canto. Hutcheon (1989, p. 47) chama a atenção para o fato de que o outro elemento constitutivo, o prefixo para, costuma ser associado apenas ao significado de contra ou oposição. Segundo argumenta, para em grego tem 
um segundo sentido: ao longo de, que também deve ser considerado por sugerir um acordo ou intimidade, potencializando a intenção pragmática da paródia, de modo a contribuir para os debates acerca das formas de arte modernas.

Assim, o último poema do livro E muitos os caminhos, de Amaral, intitulado "Em Creta, com o dinossauro", constitui uma paródia do famoso poema "Em Creta, com o Minotauro", de Jorge de Sena. Devido ao título do poema que só substitui uma palavra por outra - assim mesmo marcada por uma evidente continuidade sugerida pela rima (minotauro/dinossauro) e pela configuração da paronomásia (minotauro/dinossauro) - e ao diálogo que se estabelece em torno ao leitmotiv comum do labirinto - o monstro, o homem e a mulher-, é inevitável a aproximação entre os referidos textos poéticos.

Nosso enveredamento pela natureza textual da paródia exige que nos concentremos não somente na intimidade referida, como também na oposição engendrada pelo texto amaraliano em relação ao seniano, pois, ainda de acordo com a teoria de Hutcheon (1989, p. 48), no que diz respeito ao prefixo para com o significado de contra ou oposição, "a paródia é [...] na sua irônica transcontextualização e inversão, repetição com diferença. Está implícito um distanciamento crítico entre o texto em fundo a ser parodiado e a nova obra que incorpora, distância geralmente assinalada pela ironia".

A inversão semântica e a avaliação pragmática, segundo Hutcheon (1989, p. 73), “estão implícitas na raiz grega, eironeia, que sugere dissimulação e interrogação: há uma divisão ou contraste de sentidos, e também um questionar, ou julgar". Estas duas funções da ironia permeiam o poema "Em Creta, com o dinossauro", à medida que a substituição do "minotauro" pelo "dinossauro" prenuncia outras mudanças significativas em relação ao texto "Em Creta, com o Minotauro", de Sena (1989, p. 74), em que o poeta experimenta ampla liberdade na exposição de suas impressões de exilado, criticando explicitamente a impossibilidade de estar em sua pátria: “[...] Mas, se um dia me esquecer de tudo,/ espero envelhecer/ tomando café em Creta/ com o Minotauro $[\ldots] "$.

A respeito desse poema seniano, Cunha e Alves (2008, p. 4) sustentam que, assim como o Minotauro, o sujeito poético de Sena está encarcerado em seu labirinto/exílio, impedido de deleitar-se com sua Creta/Portugal. Eis a maneira como o sujeito está olhando o mundo: a sua pátria é recriada, dando lugar a uma Creta arquetípica, habitada por um ser imaginário com quem ele toma um café. O espaço da 
escrita também se manifesta nessa Creta, visto que, ausente da terra natal, a língua constitui o meio de o poeta interagir com o mundo. Assim, como resultado do cotejo que ora estabelecemos entre os dois poemas, cumpre-nos ressaltar que, enquanto o texto seniano é centrado no eu poético, o texto "Em Creta, com o dinossauro", de Amaral (2005, p. 243-244), confere maior relevo às personagens do "mito", especialmente Ariadne:

\section{Em Creta, com o dinossauro}

Nunca lá estive, mas gostava.

Também de me sentar à mesa de café descontraída (mesa e eu) e ter à minha frente o dinossauro.

Pata traçada sobre a rocha, aquela onde Teseu não descobrira entrada de caverna. Conversaríamos os dois, eu na cadeira, ele altamente herbívoro e escamoso, olho macio e muito social.

\section{Depois, o fio!}

Que Ariadne traria, pouco solene e debaixo do braço.

Um fio de seda ou prumo ou aço.

E o dinossauro, de pouco habituado (ainda assim) a um tempo tão nosso, perguntaria para que era aquilo.

"Para guiar Teseu", era a resposta de Ariadne. E depois, piscando o olho, ainda mais macio que o do monstro escamado, "Ou para o confundir" [...]

Por considerarmos que a manifesta mudança de ponto de vista na condução da história reflete um significativo deslocamento de valores masculinos para valores femininos e feministas, concordamos com a afirmação de Martinho (2000, p. 1) de que o poema "Em Creta, com o dinossauro" orienta-se no sentido de enfatizar mais a "diferença" do que a "repetição", termos com os quais, conforme já esclarecemos, Hutcheon (1989, p. 48) define a paródia. 
A compreensão da poesia portuguesa dos anos noventa, segundo Martelo (1999, p. 226-227), demanda que a pesquisa desenvolvida contemple a maneira como se cruzam várias estratégias compositivas (fios) na poesia amaraliana. Tais estratégias são: a combinação entre o "acontecimento mínimo" (sem grandeza ou valor aparente, sem canônica poeticidade) e o "resplendor" que de algum modo iluminaria o referido acontecimento; e o fragmento narrativo (a apresentação do que parece ser apenas a suspensão discursiva de um dos momentos de uma micronarrativa poética e que podemos subordinar à ideia de "acontecimento mínimo"), derivado de um exercício da memória ou construído como um fait-divers (o insignificante que surge repentinamente com especial significado).

No caso do poema "Em Creta, com o dinossauro", consideramos que o processo de "exaltação do mínimo" coaduna-se com a apropriação poética de uma periferia temática tradicionalmente subvalorizada como especificamente feminina. Há uma revisitação intertextual do clássico, pela referência ao episódio da mitologia grega ("O labirinto de Creta"), ilustrando, sob uma perspectiva feminina e feminista, uma Ariadne consciente de sua capacidade de, com seu fio, conduzir ou confundir Teseu e a história. Tal revisitação, conjugada com a desconstrução irônica de temas relevantes da modernidade estética, gera o fragmento narrativo, o fait-divers, a exploração da memória e o humor, impondo a este poema uma deriva entre cânone poético e periferia, desconcertando-os de um modo inovador:

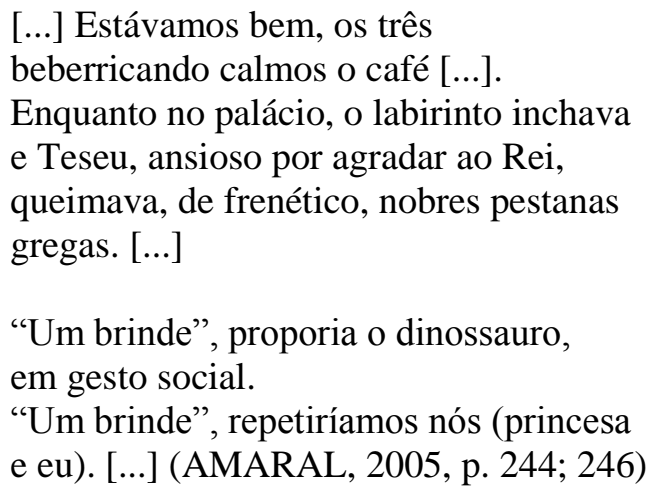

Em conformidade com o estudo de Martelo (1999, p. 226) acerca da novíssima poesia portuguesa, incluindo a de Amaral, o traço possível de ser evidenciado seria a radicalização da associação entre o "acontecimento mínimo" e o "resplendor". Nesse caso, o fato de que tal associação tenha sido instaurada em meados da década de 
sessenta, com a publicação do poema "A Magnólia”, de Luiza Neto Jorge, confirmaria a existência de um eixo de continuidade na poesia posterior à "ruptura de sessenta".

No caso de Amaral, Martelo (1999, p. 232) considera relevante o fato de que sua poesia reivindique reiteradamente uma filiação barroca, recorrendo à "torsão" sintática (marca de excesso de presença) e à elipse (marca de ausência discursiva). Com o intuito de exemplificarmos tal experiência de limites na produção de sentido da poética de Amaral (2005, p. 246, grifo da autora), selecionamos os últimos versos de "Em Creta, com o dinossauro": "[...] E o fio de renda fina voaria/ qual pássaro pré-histórico/ até ao mar Egeu./ Pata a tapar a boca de franjas/ inocentes,/ palitaria então o Dinossauro os dentes.../ (E do palácio já saiu Teseu./ Mapa e espada na mão./ Mas sem o fio.)".

Por sua vez, no âmbito da lírica contemporânea brasileira, Britto é um novo poeta que estabelece diálogo com a melhor tradição literária; a sua poesia, de acordo com a recepção de leitores especializados, possivelmente o qualifica a ingressar no futuro cânone brasileiro. Conforme Pinto (2005, p. 31), considerando-se que o modernismo se erigiu contra as formas fixas, o culto beletrista do soneto e o tom sublime, Britto é o poeta brasileiro que mais destoa das tendências atuais, visto que restaura o soneto, expondo suas variantes e combinações de modo inusitado. Os ares de renovação que Britto confere à lírica modernista surgem da conjugação lírica/antilírica, humor/rigor, engendradas a partir da exploração das possibilidades expressivas das formas fixas dentro de um tom irônico, de extração genuinamente modernista.

No que concerne à lírica de Britto, nosso foco de interesse incide, sobretudo, sobre o poema "Um pouco de Strauss", pertencente ao seu livro intitulado Trovar claro, uma vez que constitui uma paródia do conhecido poema "Procura da poesia", de Carlos Drummond de Andrade. Devido à estrutura dos versos engendrados em modo imperativo (afirmativo e, sobretudo, negativo) e ao diálogo que se estabelece no sentido de orientar o leitor sobre o processo de fazer poesia (poiesis), é evidente a aproximação entre os referidos textos poéticos.

O metapoema "Procura da poesia", de Andrade (1969, p. 36), explicita a crise moderna das noções de representação da realidade e de lirismo como expressão pessoal. A partir das formulações poéticas: "não faças versos sobre acontecimentos", "o que pensas e sentes ainda não é poesia" e "não percas tempo em mentir", podemos afirmar que, para Drummond, a poesia não pode ser concebida como resultado de simples compromisso com acontecimentos pessoais ou sociais. 
Por sua vez, no metapoema "Um pouco de Strauss", embora Britto teça uma crítica ao excesso de subjetividade na poesia ("não escreva versos íntimos, sinceros"; "não faça poesias melodiosas") - posto que a exclusão de todos os outros temas significa, inevitavelmente, condená-la ao egocentrismo -, ao mesmo tempo, sugere, nos versos finais (em que, com a expressão "vasto mundo", tece uma alusão ao "Poema de sete faces", também de Drummond), que a subjetividade é inevitável. No cerne dessa questão, cumpre-nos enfatizar a atitude irônica do poeta que segue o conselho dado ao leitor no sentido de tratar o eu com distanciamento e buscar eliminá-lo enquanto assunto ("Esquece o eu [...] / escreve pros outros"), ao mesmo tempo em que, contraditoriamente, fala sobre si, posto que, embora sob o viés da objetividade, as coisas a que o poeta se refere são as que lhe dizem respeito e o outro a quem se dirige (uma segunda pessoa, ou seja, o leitor) é um espelho, visto que ele (o poeta), ao escrever, é um leitor de Drummond (e de outros autores).

Sob a tinta da "espinafração", desde a primeira estrofe, o poeta de "Um Pouco de Strauss" estabelece uma relevante "diferenciação" em relação ao poeta de "Procura da poesia", sobretudo ao endereçar, na última estrofe, um conselho surpreendentemente atrevido ao leitor e, por extensão, a si próprio:

\section{Um pouco de Strauss}

Não escreva versos íntimos, sinceros, como quem mete o dedo no nariz. Lá dentro não há nada que compense todo esse trabalho de perfuratriz, só muco e lero-lero.

Não faça poesias melodiosas e frágeis como essas caixinhas de música que tocam a "Valsa do Imperador". É sempre a mesma lengalenga estúpida, sentimental, melosa.

Esquece o eu, esse negócio escroto e pegajoso, esse mal sem remédio que suga tudo e não dá nada em troca além de solidão e tédio: escreve pros outros.

Mas se de tudo que há no vasto mundo só gostas mesmo é dessa coisa falsa que se disfarça fingindo se expressar, então enfia o dedo no nariz, bem fundo, e escreve, escreve até estourar. E tome valsa. (BRITTO, 1997, p.56) 
Portanto, o leitor que perscruta o "vaivém" intertextual entre os poemas "Em Creta, com o dinossauro" e "Em Creta, com o Minotauro", ou entre os poemas "Um Pouco de Strauss" e "Procura da poesia", como já o fizemos, frui o prazer da ironia entre a "duplicação textual (que unifica e reconcilia)" e a "diferenciação (que coloca em primeiro plano a oposição irreconciliável entre textos e entre texto e 'mundo')" - termos da teoria de Hutcheon (1989, p. 129) que utilizamos para elucidar a paródia de Amaral e de Britto.

Afinal, a verdadeira intertextualidade, segundo Perrone-Moisés (1979, p. 214), implica a eliminação tanto da fronteira textual (a que demarca os direitos de autor, de propriedade) quanto da fronteira discursiva (a que se refere aos gêneros discursivos e tem como função separar o discurso poético e o discurso crítico). Nossa pesquisa levanos a considerar que Amaral e Britto rompem as referidas fronteiras, porque, buscando novas formas de expressão, ambos apresentam ao leitor uma espécie de escrita-crítica, resultado do trabalho de um escritor-crítico. E assim se realiza o circuito comunicativo literário, pois, conforme a estética da recepção de Jauss (1982), o produtor é também um receptor quando começa a escrever.

Portanto, cada um dos poemas "Um Pouco de Strauss" e "Em Creta, com o dinossauro" comporta três personas - o leitor, o crítico e o poeta - com voz única na poesia. Nesse âmbito, as considerações elaboradas por Perrone-Moisés (1998, p. 5-27) acerca da linhagem de escritores-críticos na tradição literária ocidental mais recente convida-nos a instigantes reflexões.

Britto, professor universitário de literatura, torna-se um escritor-crítico, porque escreve, além de poesia, ficção e tradução literária, textos críticos. Por sua vez, Amaral, também professora universitária de literatura, torna-se uma escritora-crítica, pois escreve, além de poesia, literatura infantil e tradução literária, textos críticos. Cabe-nos sublinhar a relevância particular das escolhas críticas como valorações dinâmicas do passado, uma vez que as obras lidas instigam as respostas do escritor-crítico Britto e da escritora-crítica Amaral, seja por meio de discursos críticos, seja por meio de suas próprias obras - respostas articuladas às obras anteriores. No caso de cada um deles, a seleção de sua própria tradição configura uma proposta de novos cânones e a prática de formas particulares de intertextualização no estabelecimento de diálogo com os autores do passado e do presente. 
Enfim, esse fenômeno do escritor-crítico Britto, que convoca o passado ao momento presente, movido pela premência de uma escolha que situe, oriente e valorize sua própria práxis atual, leva-nos a refletir sobre os valores da modernidade e nos autoriza a usar a crítica de Britto para o poeta Britto, visto que seu artigo intitulado "Poesia e memória" mapeia seus percursos históricos e suas revisões do passado. No referido artigo, Britto (2000, p. 127-131) afirma que a poesia "pós-lírica", propondo a ideia de que a realidade consiste em um entrecruzar de textos, tende a conferir mais importância à intertextualidade ("memória lida") do que à experiência não-literária (“memória vivida"). Nesse sentido, "o eu por trás dos poemas é essencialmente uma encruzilhada de textos", em que a substituição das experiências existenciais pelas leituras feitas é completa. No que concerne a "Um Pouco de Strauss", consideramos que a poesia de Britto se apresenta como crítica e reescritura dos poemas de Drummond, predecessor eleito pelo poeta para seu paideuma pessoal, ao mesmo tempo em que configura um sujeito que está presente mesmo quando tenta lançar-se em abismo. Britto, com sua expressão literária pós-aurática, empenha-se, ostensivamente, em dessacralizar a poesia e, por extensão, em provocar os leitores engessados em fórmulas de contemplação estética incompatíveis com a ousadia discursiva praticada pelo autor.

Quanto a "Em Creta, com o dinossauro", o diálogo com a tradição, urdido via paródia e humor, configura uma intertextualidade labiríntica, caminho escolhido por Amaral (2005, p. 245), poeta que, imersa na tensão entre presente e passado cultural, sacralização e dessacralização da poesia, indaga, no cerne da própria práxis do poema, o locus crítico da poesia no mundo contemporâneo: “[...] 'É como o fio que eu trago/ aqui, para Teseu', Ariadne/ diria, 'O de aço, seda, ou prumo,/ que conduz ou confunde, conforme/ ocasião' [...]".

Um cotejo entre "Um Pouco de Strauss", de Britto, e "Em Creta, com o dinossauro", de Amaral, sugere que, em cada um desses poemas, o lugar do contemporâneo fez seu próprio caminho. Afinal, quanto ao diálogo possível entre a atual produção poética brasileira e portuguesa desses e de outros autores, parece-nos que há uma unanimidade crítica que aponta para o fato de que, na contemporaneidade (entendida como singular relação com o próprio tempo), nada está sendo convencionado. $\mathrm{O}$ contexto de singularidade e pluralidade em que se insere a poesia lírica contemporânea do Brasil e de Portugal suscita dificuldades no que concerne ao estabelecimento de seus parâmetros críticos, pois cada poeta é diverso em relação aos 
demais poetas recentes do país-irmão e de seu próprio país, bem como de uma obra para outra.

Em suma, se alguma aproximação pode haver entre os poemas "Um Pouco de Strauss" e "Em Creta, com o dinossauro" ocorre em mínimas intersecções, sugerindo que, embora em cada um deles haja linhas de continuidade com o passado, os fios que se retomam são plurais e diversificados. Essa questão se elucida se partirmos do pressuposto de que a memória pessoal e a literária, bem como o recuo pelo humor e pela ironia, são elementos fulcrais para caracterizar esses exemplares da poesia brasileira e portuguesa mais recente; contudo, cada qual apresenta o seu modo particular de tensionar a historicidade literária e a historicidade circunstancial em que se inscreve. Enfim, tecendo a poesia lírica contemporânea com ironia, cada uma dessas escritas responde, à sua maneira, à perda da ilusão da unidade autoral e da originalidade, numa espécie de autolegitimação.

\section{REFERÊNCIAS BIBLIOGRÁFICAS:}

AMARAL, Ana Luísa. Poesia reunida: 1990-2005. Vila Nova de Famalicão: Edições Quasi, 2005.

ANDRADE, Carlos Drummond de. Reunião - 10 livros de poesia. Rio de Janeiro: José Olympio, 1969.

BARBOSA, João Alexandre. As ilusões da modernidade. In: As ilusões da modernidade. São Paulo: Perspectiva, 1986, p. 9-37.

BRITTO, Paulo Henriques. Trovar claro. São Paulo: Companhia das Letras, 1997.

Poesia e memória. In: PEDROSA, Célia (Org.). Mais poesia hoje. Rio de

Janeiro: 7 Letras, 2000, p. 124-131.

CUNHA, Kassia Fernandes de; ALVES, Ida Ferreira. Algumas intrigantes paisagens das metamorfoses senianas. In: XI Congresso Internacional da ABRALIC - Anais do XI Congresso da ABRALIC: 2008, São Paulo. Tessituras, Interações e Convergências. São Paulo: ABRALIC, 2008. p. 1-7.

HUTCHEON, Linda. Uma teoria da paródia. Tradução de Teresa Louro Péres. Lisboa: Edições 70, 1989.

JAUSS, Hans Robert. Toward an aesthetic of reception. Tradução de Timothy Bahti. Minneapolis: University of Minnesota Press, 1982.

KRISTEVA, Julia. Introdução à Semanálise. Tradução de Lúcia Helena França. São Paulo: Perspectiva, 1974.

MARTELO, Rosa Maria. Anos noventa: breve roteiro da novíssima poesia portuguesa. In: Via Atlântica, São Paulo, n. 3, p. 224-233, 1999.

MARTINHO, Fernando J. B. Depois do Modernismo, o quê?: o caso da poesia portuguesa. In: Semear - Revista da Cátedra Padre Antônio Vieira de Estudos Portugueses, Rio de Janeiro, n. 4, p. 1-2, 2000. 
NUNES, Benedito. A recente poesia brasileira: expressão e forma. In: Novos estudos CEBRAP, São Paulo, n. 31, p. 171-183, out. 1991.

PERRONE-MOISÉS, Leyla. A intertextualidade crítica. In: Poétique. Intertextualidades. Tradução de Clara Crabbé Rocha. Coimbra: Livraria Almedina, n.27, p. 209-230, 1979.

. Altas literaturas: escolha e valor na obra crítica de escritores modernos. São Paulo: Companhia das Letras, 1998.

PINTO, Manuel Costa. Um esboço do futuro cânone brasileiro. In: Revista Entrelivros, São Paulo: Ediouro; Duetto Editorial, n. 5 (1), p. 30-34, set. 2005.

SENA, Jorge de. POESIA III. Lisboa: Edições 70, 1989. 